\title{
The comparison of spiritual health in cancer and non-cancer patients in Sanandaj, Tohid Hospital in 2018
}

\author{
Roonak Mobaraki', Fayegh Yousefi ${ }^{2}$, Gholamreza Esfandiari ${ }^{3}$ \\ 1-Msc, Spiritual Health Research Center, Kurdistan University of Medical Sciences, Sanandaj, Iran. \\ 2- Associate Professor, Spiritual Health Research Center, Kurdistan University of Medical Sciences, Sanandaj, \\ Iran(Corresponding Author). $\quad$ E-mail: F.yousefi@muk.ac.ir \\ 3- Master of Clinical Psychology, Department of Psychiatry, Kurdistan University of Medical Sciences, \\ Sanandaj, Iran.
}

Received: 12/09/2019 Accepted: 30/12/2019

\begin{abstract}
Introduction: Due to nature of the cancer threat, the diagnosis of this disease causes the spiritual needs of patients to increase dramatically.

Aim: This study was conducted to Comparison of Spiritual Health in Cancer and Non-Cancer Patients in Sanandaj, Tohid Hospital in 2018.

Method: This case-control study was conducted in Tohid Hospital in Sanandaj in 2018. The research population consisted of 60 cancer patients admitted to Tohid Hospital. The instrument of data was questionnaire and the data was collected using a simple sampling method. For data analysis, descriptive statistics, correlation test used by SPSS Software. Results: The results of this study showed that there was not significant relationship between two groups ( $\mathrm{p} \geq 0.05$ ).

Conclusion: It is recommended that the promotion of spiritual health in diseases such as cancer, which affects the body and the minds of individuals, should be considered as specific, because promoting spiritual health will improve the physical and mental health of the patient.
\end{abstract}

Keywords: Spiritual Health, Cancer, Patients

How to cite this article : Mobaraki R, Yousefi F, Esfandiari Gh. The comparison of spiritual health in cancer and non-cancer patients in Sanandaj, Tohid Hospital in 2018. Shenakht Journal of Psychology and Psychiatry. 2020; 6 (6): 141-149 .URL: http://shenakht.muk.ac.ir/article-1-877-fa.pdf

Copyright (C) 2018 the Author (s). Published by Kurdistan University of Medical Sciences. This is an open access article distributed under the terms of the Creative Commons Attribution-Non Commercial License 4.0 (CCBY-NC), where it is permissible to download, share, remix, transform, and buildup the work provided it is properly cited. The work cannot be used commercially without permission from the journal. 


\title{
بررسى مقايسه سلامت معنوى در بخش سرطان و همر اهان بخشهاى غير سرطان بيمار ستان توحيد شهر ستان سنندج در سال
}

\author{
روناكى مبار كى'، فايق يوسفى'، غلامرضا اسفنديارى'

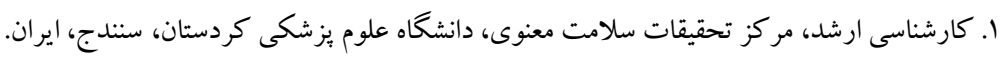

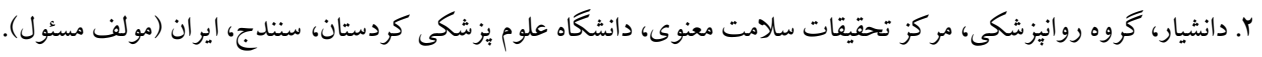 \\ ايميل: F.yousefi@muk.ac.ir \\ r. كارشناسى ارشد روانشناسى بالينى، گروه روانيز شكى، دانشكاه علوم يزشكى كردستان، سندج، ايران.

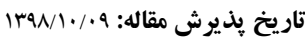

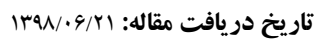

مقدمه: به علت طبيعت تهلديدكنندى سرطان، تشخيص اين بيمارى سبب مىشود كه نيازهاى معنوى بيماران به طور جشمخيرى افزايش يابد. هدف: اين مطالعه با هدف مقايسه سلامت معنوى بيماران مبتلا به سرطان در سال Vوسا در بيمارستان توحيد سنندج انجام كرفته است.

روش: اين مطالعهى مورد شاهد بوده است. جامعهى يزوهش، شامل •9 نفر از بيماران مبتلا به سرطان بسترى در بيمارستان توحيد

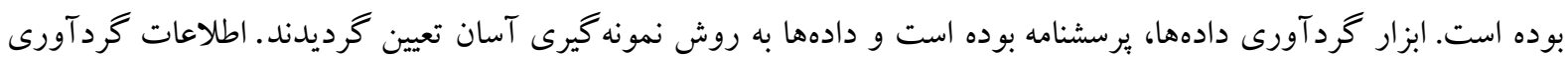

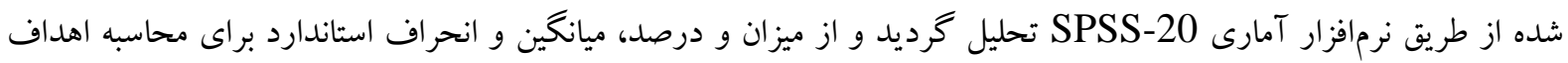

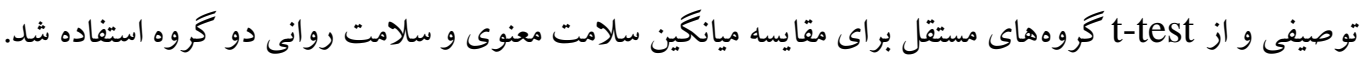
يافتهها: نتيجهى اين مطالعه نشان داد بين دو گروه مورد مطالعه رابطه معنىدارى وجود ندارد (ه•/p نتيجه كيرى: توصيه مىشود ارتقاى سلامت معنوى در بيمارىهايى همجيون سرطان كه بر جسم، روان و روح افراد تأثير كذار

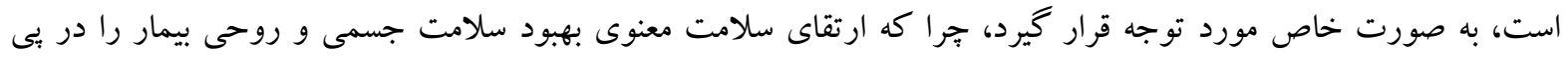

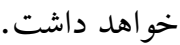
كليد وازهها: سلامت معنوى، سرطان ، بيماران 
كوناكون مواجهه و مقابله با عوارض ناشى از مشكلات

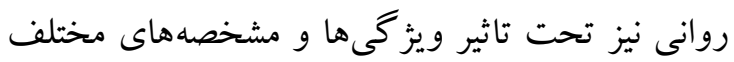
افراد و اقشار مختلف خواهد بود. مذهب راهى است كه اهداف زندگى را تفسير كرده و به آن حواد آنساد موجود معنا و ساختار مىبخشد و وسيله اى است براى

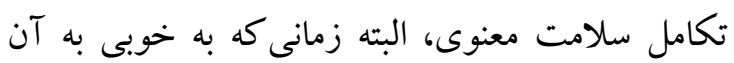
تمسك جسته شود. سلامت معنوى يكى از ابعاد مهم

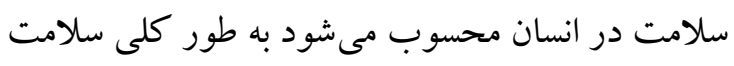
معنوى ارتباط هماهنگك و يكهارجه را بين نيروهاى

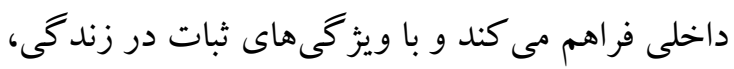

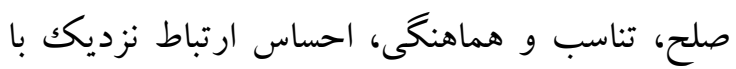
خويشتن، خدا، جامعه و محيط مشخص مىشود.

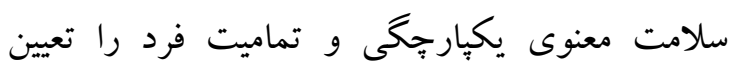

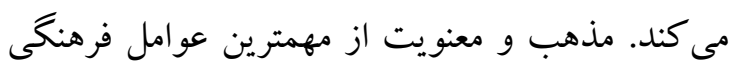
هستند كه به ارزشهاى انسانى، رفتارها، تجربيات و و وهنو ساختار معنا مىدهند (دستغيب و همكاران، سوبا إ). به دليل طبيعت تهديدكننده سرطان، تشخيص اين بيمارى موجب مى شود نيازهاى معنوى بيماران به طور جشمخيرى افزايش يابد. اين نيازها بحرانهاى معنايى مئي بسيارى در فرد ايجاد مى كند؛ اعتماد به نفس و ايمان

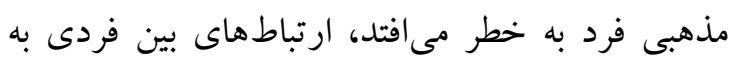

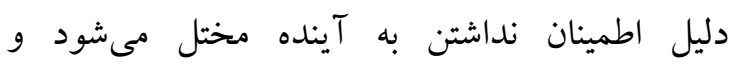
سازو كارهاى قبلى ناكافى به نظر مىرسد، همبحنين

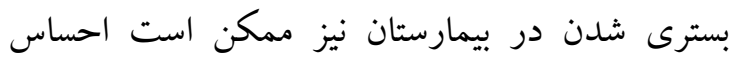
تنهايى را به فرد القا كند و در يكك كلام مى توان كفت بنت

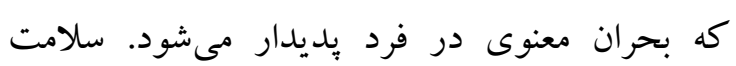
معنوى يكى از ابعاد مهم سلامت محسوب مى بودود،

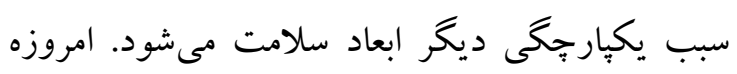

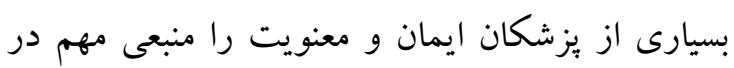
سلامت جسمى و بهبود اقراد مىشناسند، به كونه اي اي كه آنان اغلب ضرورى مىدانند كه در فرايند درمان به به به به مسائل معنوى بيماران توجه كنند. مذهب و معنويت معرديت
مقلهمه سلامتى حالتى است كه نه تنها به كار كردهاى بلدنى فرد بلكه به بسيارى از جنبهاى روانى نيز وابسته است. سازمان بهداشت جهانى سلامتى را جنين تعريف كرده است: سلامتى عبارت است از رفاه كامل جسمى،

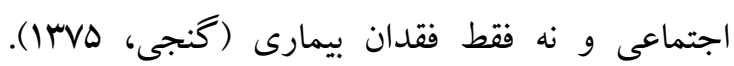
امروزه سلامت روان يكى از گُرفتارىهاى مهم و روبه افزايش خانواده ها، سازمان ها و و جوامع است. كارشناسان سازمان بهداشت جهانى بر اين باورند كه

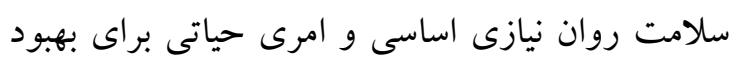

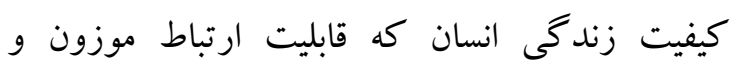
هماهنگى با ديخران، تغيير و اصلاح محيط فردى و اجتماعى و حل تضادها و تمايلات شخصى به طور منطقى، عادلانه و مناسب است. در تعريف سلامت روان بايد گفت هر انسانى كه بتواند با مسايل عميق

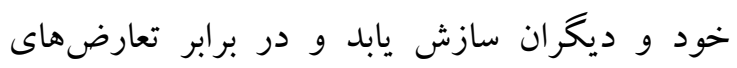
اجتناب نايذير درونى خود فلج نشود و خود را به وسيله جامعه مطرود نسازد. و داراى احساس خوب بودن و و

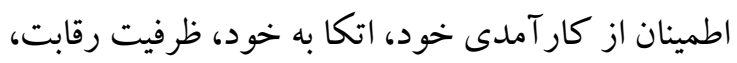
تعلق بين نسلى و خودشكوفايى، توانايىهاى بلقوه،

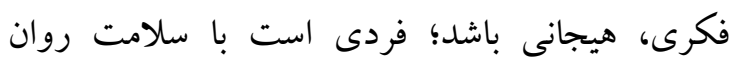
(دستغيب و همكاران، سوبr). سلامت روان صرفأ نداشتن بيمارىهاى روانى نيست هانت بلكه توان واكنش در برابر انواع تجربيات زندكى به روان

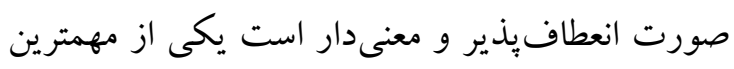

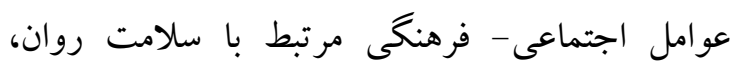
سلامت معنوى است. گرجه ترديدى نيست كه افر اد در

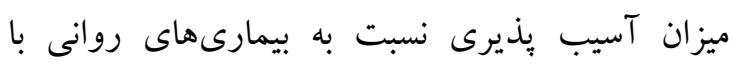
يكديخر تفاوتهاى زيستى و فردى دارند، اما مساله اين است كه ميزان اين تفاوتها تحت تاثير موقعيت

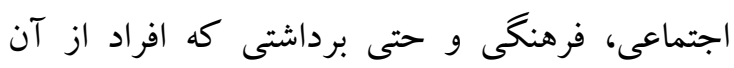

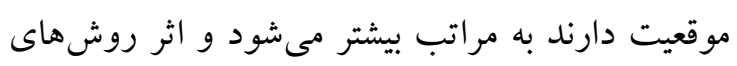


همبستخى آن با مشكلات جسم بوده است و با تقويت بعد معنوى مى توان به ارتقاى سلامت عمومى و كاستن اختلالات روانى و كاهش تمايل به مصرف مواد و مصرف مواد و استمرار دوره اعتياد را به همراه داشته باشد (نقيبى و همكاران، سهبا). در مطالعه ديخر مشخص گرديد سلامت روانى سالمندان توسط متغيرهاى بهزيستى مذهبى، بهزيستى وجودى، سرسختى روانشناختى و سن به خوبى قابل بيشبينى است. نتايج اين تحقيق، تلويحات مهمى در خصوص اهميت بهزيستى معنوى و سرسختى روانشناختى در حفظ سلامت روانى سالمندان داشت (جعفرى و همكاران، •وr I). سلامت روان در جانبازان با بهزيستى معنوى و. رضايت از زندگى ارتباط مثبت معنىدار دارد (هاشميان و همكاران، سهب ا). با توجه به مطالب فوق، هدف اين مطالعه مقايسه سلامت معنوى در بخش سرطان و همراهان بخشهاى غير سرطان بيمارستان توحيد شهرستان سندج در سال V9r I" مىباشد.

روش اين تحقيق از نوع مورد- شاهدى انجام شده است. جامعه مورد مطالعه آن كليه بيماران بسترى در بخش

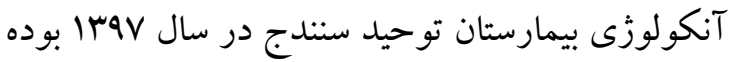

حجم نمونه مورد بررسى در اين مطالعه با اطمينان 9ه٪٪ و توان آزمون •م درصد و با توجه نبود شيوع سلامت معنوى در مطالعههاى قبلى، در دو گروه (براى هر گروه

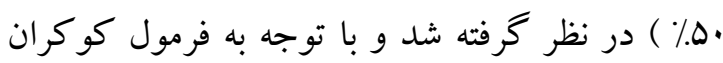
حداقل نمونه در هر گروه Fه نفر است كه در مجموع M M نفر مىباشد. نحوه گردآورى اطلاعات در اين هره

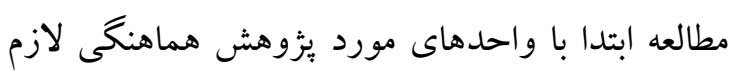
بعمل آمد و در مرحله بعدى به شكل نمونه گيرى در دسترس بيماران بخش آنكولوزى انتخاب كرديند و
مجموعهاى از كلمات و جهارجوبهها را مشخص مى كند كه از راه آنها انسان مىتواند معنا و مفهوم زندگى خود را درك كند (مرادى جو و همكاران،

.$(1) 90$

از اصطلاح سلامت روانى براى بيان و اظهار كردن هدف خاصى براى جامعه استفاده مىشود. هر فرهنگ برك براساس معيارهاى خاص خود به دنبال سلامت روانى

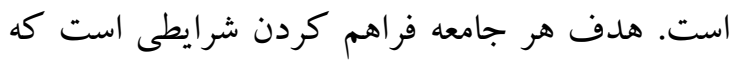
سلامت اعضاى جامعه را تضمين كند؛ زيرا سلامت روانى قسمتى از سلامت كلى و عمومى است. منظور از سلامت روانى، سلامت ابعاد خاصى از انسان مانند

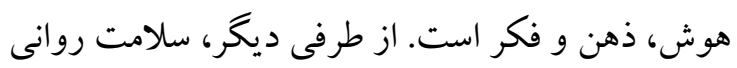
بر سلامت فيزيكى هم تاثير دارد. يثزوهشهاى اخير ثابت كردهاند كه يكسرى اختلالهاى فيزيكى و جسمى لئى به شرايط روانى مرتبط اند. با وجود اينكه سلامت روان مفهومى وسيع است كه خيلى وسيع از آن استفاده مىشود، اما هنوز تعرفى كلى كه مورد قبول همه باشد از آن به دست نداده اند (سليمانى، هوبـا). به نظر مىرسد از دست دادن توكل و مقا (به دليل داشتن احساس رهاشدگى توسط خداوند متعال) با سلامت روان بايينتر و راهكارهاى مقابلهاى ضعيفتر در ارتباط است. ازاينرو معنويت و مذهب به به عنوان سبرى در برابر مشكلات و ناراحتىهاى افراد قرار گرفته و به صورت ضربه گير عمل مى كند و موجب كاهش اختلالات روانى و ارتقاى سلامت روانى مى شود

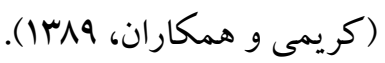
نتايج مطالعهاى نشان داد سلامت معنوى بيشتر بيماران مبتلا به سرطان در حد متوسطى قرار دارد و دجار بهار مشكل سلامت عمومى خفيفى هستند و بين سلامت عمومى و سلامت معنوى رابطه معنىدارى وجود دارد. همجِنين نتيجه مطالعه نشان داد بيشترين همبستخى سلامت معنوى با بعد كاركرد اجتماعى و كمترين 
ابزار گردآورى اطلاعات در اين مطالعه شامل: يرسشنامه سلامت معنوى: از يرسشنامه سلامت معنوى (19AY) يولوتزين و اليسون استفاده شد. اين برسشنامه

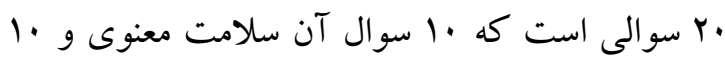
سوال ديخر سلامت وجودى فرد را بررسى مى كند. نمره گذارى سلامت معنوى جمع دو زير گروه سلامت مذهبى و سلامت وجودى است كه دامنه نمرات كسب

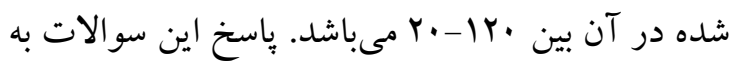

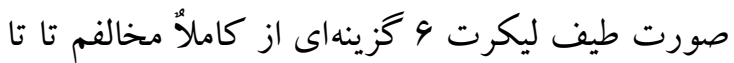
كاملاً موافقم دسته بندى شده است. با توجه به دستور العمل برسشنامه در صورت كسب نمره بين سلها

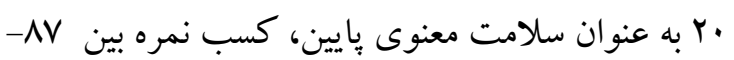
اله به عنوان سلامت معنوى متوسط و كسب نمره . DF M به عنوان سلامت معنوى بالا در نظر گرفته مىشود. روايى برسشنامه سلامت معنوى از طريق اعتبار محتوا مشخص و تأييد شد و بايايى آن از طريق الفا كرونباخ

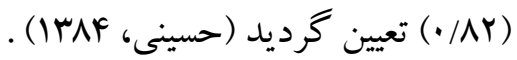

\section{يافته ها} نتايج اين مطالعه نشان مىدهد كه ميانخين سن گروه

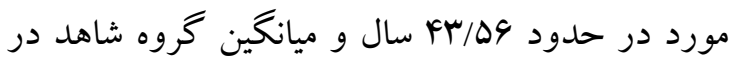

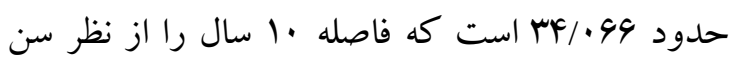
ياسخگويان دو گروه مىدهد. ميانگين سنى كل

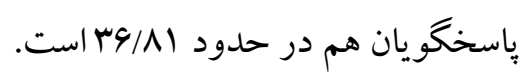

با توجه به اطلاعات جدول لا، فراوانى مدركك تحصيلى كروه شاهد در سطح كارشناسى ارشد و بالاتر بيشتر از

$$
\text { كروه مورد بوده است. }
$$

توجيه كامل شدند و از آنان رضايت آكاهانه جهت شر كت در مطالعه گرفته شد. سيس با توجه به معيارهاى إن ورود و خروج مطالعه اقدام به يركردن يرسشنامه ها كرديد و در مرحله بعد ، به اندازه گرووه مورده،

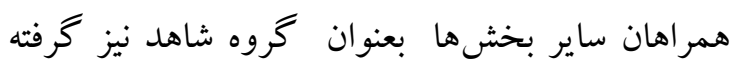
شد. لازم به توضيح است كه گرووه مورد و شاهد از نظر سن همتاسازى شدند. در ضمن، جون در برسشنامه اسامى بيماران نوشته نشد لذا، اطلاعات بيماران كاملا محرمانه بوده است و هيج گونه اطلاعاتى كه نشان بدهد يرسشنامه مربوط به جه كسى است گرفته نشد.

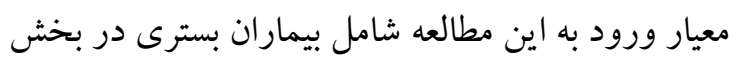
آنكولوزى و يكك بخش مجاور در بيمارستان توحيد

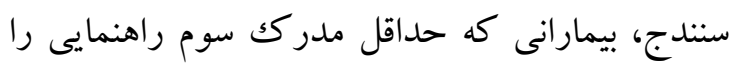
داشته باشند و معيار خروج از مطالعه براى جمعيت مورد مطالعه شامل بيمارانى كه براى شركت در مطالعه رضايت نداشته باشند، بيمارانى كه از لحاظ بهره هوش بـ بهر در سطح بايين بوده باشند بر اساس ظن بالينى و بيماران

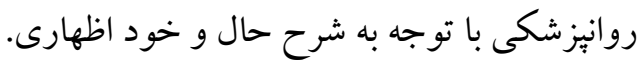

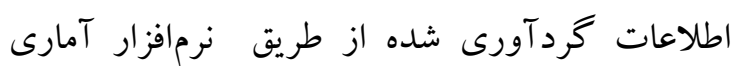
SPSS-20 ميانگين و انحراف استاندارد براى محاسبه اهداف توصيفى و از t-test خروههاى مستقل براى مقايسه

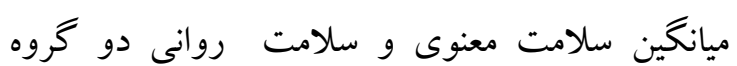

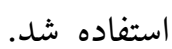

\begin{tabular}{|c|c|c|}
\hline شاهد ( فراوانى و درصد) & مورد( فراوانى و درصد) & متغير ها \\
\hline \multicolumn{3}{|c|}{ تحصيلات } \\
\hline$(G / V) r$ & $(Y G / V) \wedge$ & بى سواد \\
\hline
\end{tabular}

جدول ا توزيع فراوانى متغير هاى مورد مطالعه در دو كروه مورد و شاهد 


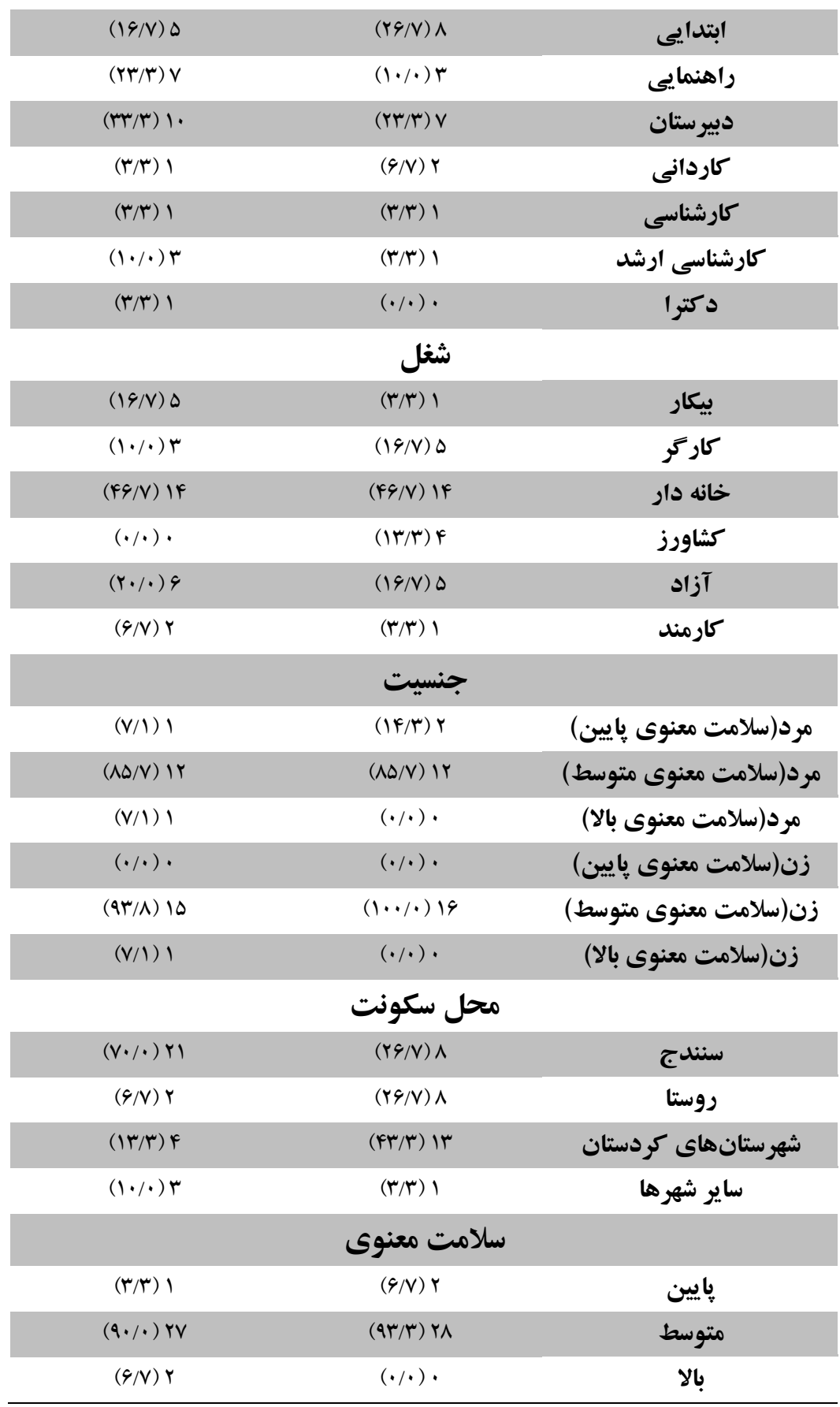

سلامت معنوى پِايين هستند در صورتى كه هيجکكدام

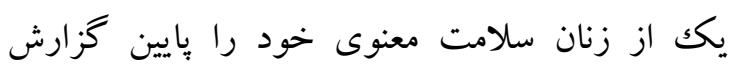

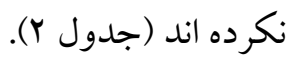

در بررسى ميزان سلامت معنوى بين دو جنس از طريق

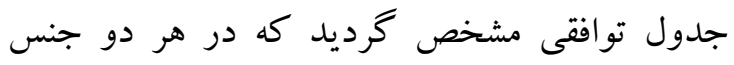
اكثريت داراى سلامت معنوى متوسط هستند و اما در

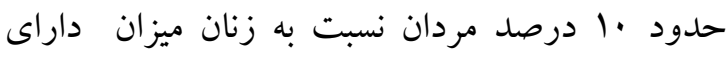


جدول r توزيع فراوانى سلامت معنوى بر حسب جنسيت

\begin{tabular}{|c|c|c|c|c|}
\hline \multirow[b]{2}{*}{ جمع كل } & \multicolumn{3}{|c|}{ ميزان سلامت معنوى } & \multirow[b]{2}{*}{ جنسيت } \\
\hline & سلامت معنوى هايين & سلامت معنوى متوسط & سلامت معنوى بالا & \\
\hline rA & $r(1 \cdot / v)$ & $\operatorname{rF}(\Lambda \Delta / V)$ & $1(r / 9)$ & مذكر \\
\hline rr & $\cdot \quad(\cdot)$ & MI (94/9) & $1(r / 9)$ & مونث \\
\hline $4 \cdot(1 \cdots)$ & $r(\Delta)$ & $\Delta \Delta(91 / \mathrm{V})$ & $r(r / \Gamma)$ & جمع كل \\
\hline
\end{tabular}

همانطور كه در جدول ب مشاهده مىشود گروه شاهد و مورد از نظر سلامت معنوى با يكديخر تفاوتى ندارد.

جدول ץ تفاوت ميانكين سلامت معنوى در دو زروه

\begin{tabular}{|c|c|c|c|c|}
\hline سطح معنى دارى & $\mathbf{t}$ & ميانكين & ياسخگَويان & متغير ها \\
\hline \multirow[t]{2}{*}{$\cdot / r V \Delta$} & \multirow[t]{2}{*}{$1 / Y \cdot Y$} & $99 / 1$. & مورد & \multirow[t]{2}{*}{ سلامت معنوى } \\
\hline & & $90 / 99$ & شاهد & \\
\hline
\end{tabular}

نتيجهى اين مطالعه نشان داد، در سطحبندى سلامت معنوى، بسيارى از بيماران مبتلا به سرطان، سلامت معنوى در سطح متوسطى داشتهاند كه با در نظر گرفتن غلبهى فرهنگ مذهبى در جامعهى ايرانى، اين امر طبيعى به نظر مىرسد. بنابراين توصيه مىشود ارتقاى

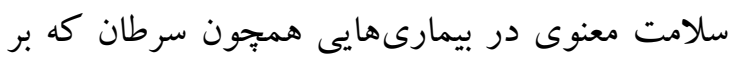
جسم، روان و روح افراد تأثير گذار است، به صورت خاص مورد توجه قرار گيرد، جرا كه ارتقاى سلامت دون معنوى بهبود سلامت جسمى و روحى بيمار را در بيى خواهد داشت كه مساله با نتايج مطالعهاى همخوانى دارد جرا كه نتايج اين مطالعه حاكى از اين است سطح سلامت معنوى اين بيماران در محدوده بالا قرار دارد.

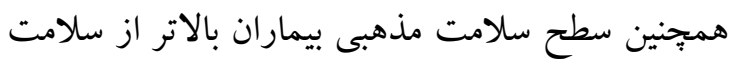

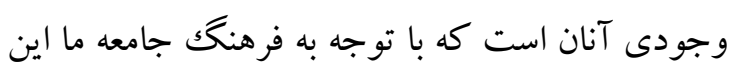
امر طبيعى به نظر مىرسد (رضايى و همكاران، IrAV). در همين رابطه ، نتايج مطالعه ديخرى نشان داده است كه ميانگين نمرات سلامت معنوى و و اميد در بيماران كروه آزمايش به طور معنادارى بيشتر از گروه كنترل
اين نتيجه بر مبناى آزمون t دو گروه مستقل به دست

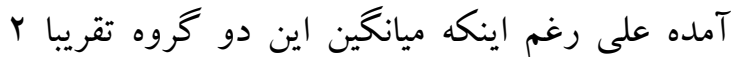

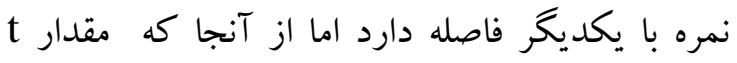

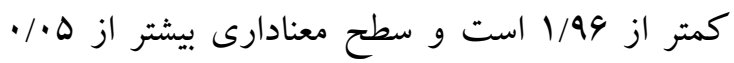

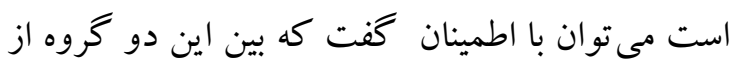
نظر سلامت معنوى تفاوتى وجود ندارد.

يثوهش حاضر با هلف بررسى مقايسه سلامت معنوى در بخش سرطان و همراهان بخشهاى غير سرطان بيمارستان توحيد شهرستان سنتدج در سال IM9V انجام شده است. نتيجهاى اين ئزوهش نشان داد، اكثر ياسخگُ يان داراى سطح سلامت معنوى متوسط هستند اين نتيجه با نتايج مطالعهى ديخرى كه بر نقش سلامت معنوى بر اميد به زندكى و بهداشت روانى تاكيد شده است همخوانى دارد (رضايى شهسوارلو و همكاران،

.(1rar 


\section{سياسگزارى}

از تمامى بيماران، برسنل و مديريت بيمارستان توحيد

سندج و مخصوصاً بخش سرطان اين بيمارستان به به بيه خاطر همكارى صميمانه و مناسب خود در زمينه انجام اين تحقيق تشكر مى شود.

\section{References}

Dastgheib Z, Gharlipour Z, Ghobadi Dashdebi K, Hoseini F, Vafaee R. (2015). Association of between mental health and spiritual health among students in Shiraz University. Advances in Nursing \& Midwifery of Shahid Beheshti University of Medical Sciences, Tehran, Iran . 24(84):53-9

Ganji H. (1997). Psychological Sanctions (Second Edition, The Disciple of Arasbaran.

Hashemian SA, Khademi MJ. (2015). The Survey of Veterans' Mental Health Based on Spiritual Well-Being and Life Satisfaction. J Mil Med. 16 (4) :205-209.

Hosseini F. (2006). Prayer \&spiritual well -being in patients with cancer. Payesh Quarterly. 5(4): 295-304.

Jafari E, Hajloo N, Faghani R, Khazan K. (2012). The relationship between spiritual well-being, hardiness, and mental health in the elderly. Journal of Research in Behavioral Science (JRBS). 10(6); 431-440.

Kamian S, Taghdisi MH, Azam K, Estebsari F, Ranjbaran S, Geravand A. (2014). Evaluating Effectiveness of Spiritual Health Education on Increasing Hope among Breast Cancer Patients. Iran J Health Educ Health Promot. 2 (3) :208-214.

Karimi L, Shomoossi N, Safee Rad I, Ahmadi Taho M. (2011). The relationship between spiritual well-being and mental health of University students. Joumal of Sabzevar University of Medical Sciences. 17(4); 274 280.

Kazemi M, Heidari S, Azimpoor A, Babaloo T, Baljani E. (2018). The Impact of Spiritual Counseling on Life Satisfaction of Patients With Cancer. A Clinical Trial Study. Avicenna J Nurs Midwifery care. 26 (5) :298-305.
بوده است و در مطالعه فوق بر نقش آموزش سلامت معنوى تاكيد شده است (كاميان و همكاران، بوج ا ). نقش باورهاى معنوى و توجه به ارزشها و اخلاق و پايبندى به بر سلامت معنوى و روانى در مطالعات متعددى تاكيد شده است طورى كه منابع مذهبى و ورى

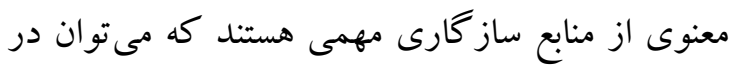

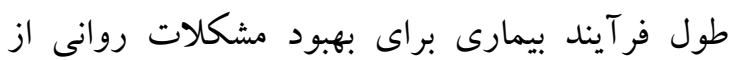
جمله ناميدى در مبتلايان به سرطان از آنها استفاده نمود (مقيميان و سلمانى، • • (1) ).

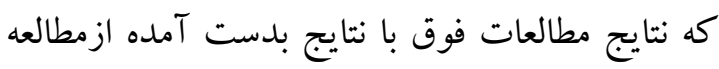

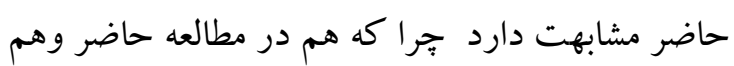

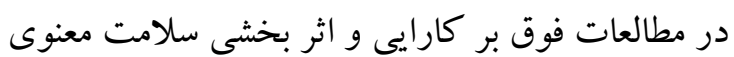
بر سلامت روانى بيماران تاكيد شده است.

با توجه به نقش معنويات بر سلامت روانى بيماران مبتلا

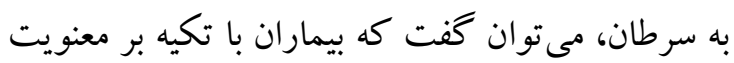

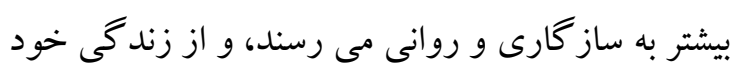

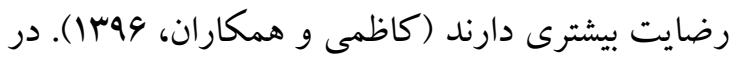

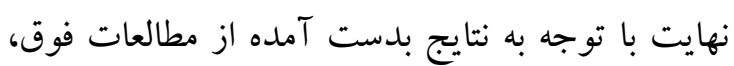
مىتوان كفت با نتايج مطالعه حاضر هم خوانى دارند. اين مطالعه محدوديتهاى نيز همراه داشته است از جمله مىتوان اشاره كرد به غيرتصادفى بودن نمونه گيرى، و همجينين اين موضوع كه جامعهى آمارى را تنها بيماران مبتلا به سرطان مراجعه كننده به بيمارستان توحيد سنتدج تشكيل مىدادند، لذا نمى توان اين نتايج را تعميم داد.

\section{نتيجه كيرى}

با توجه به نتايج بدست آمده از اين مطالعه ، مىتوان

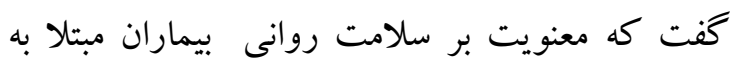
سرطان تاثير دارد لذا بيشنهاد مى شود براى بيماران فوق، كلاسهاى آموزشى ومداخلات روانشناختى مبتى بر

$$
\text { معنويت بركزار كردد. }
$$


Moghimian M, Salmani F. (2012). The Study of Comelation between Spiritual well-being and Hope in Cancer Patients Referring to Seyyedo Shohada Training-Therapy Center of Isfahan University of Medical Sciences, 2010, Isfahan, Iran. Qom Univ Med Sci J. 6 (3):40-45.

Mohamad karimi M, Shariatnia K. (2017). Effectiveness of spiritual therapy on the life quality of the women with breast cancer in Tehran. J Urmia Nurs Midwifery Fac. 15 (2):107-118.

Moradi-Joo M, Babazadeh T, Honarvar Z, MohabatBahar S, Rahmati-Najarkolaei5 F, Haghighi M. (2017). The Relationship between Spiritual Health and Public Health Aspects among Patients with Breast Cancer. Journal of Research on Religion \& Health. 3(3): 8091.

Naghibi SA, Ashari S, Rostami F, Hosseini SH. (2015). Evaluation of the Relationship between Spiritual Health and Mental Health in Patients Undergoing Methadone Maintenance Treatment . J Health Res Commun. 1 (3) :61-69

Rezaei M, Seyedfatemi N, Hosseini F. (2009). Spiritual Well-being in Cancer Patients who Undergo Chemotherapy. Hayat. 14 (4 and 3):33-39.

Rezaie Shahsavarloo Z, Lotfi M, Taghadosi M, Mousavi M, Yousefi Z, Amirkhosravi N. (2013). Relationship between components of Spiritual well-being with hope and life satisfaction in elderly cancer patients in Kashan.jgn. 2015; 1 (2) :43-54.

Soleimani E. (2017). The relationship between mental health and quality of life with mediating role of health Spirituality in Students. Culture in The Islamic University. 6(4):568-71. 